\title{
Involvement of the accessory gene regulator (agr) in expression of type 5 capsular polysaccharide by Staphylococcus aureus
}

\author{
Bruno Dassy, ${ }^{1,2 *}$ Teresa Hogan, ${ }^{3}$ Timothy J. Foster ${ }^{3}$ and Jean-Michel Fournier ${ }^{1}$ \\ ${ }^{1}$ Département d'Ecologie, Institut Pasteur, F-75724 Paris Cedex 15, France \\ ${ }^{2}$ UFR des Sciences de la Vie, Division de Biochimie, Université Pierre et Marie Curie, F-75252 Paris Cedex 05, \\ France \\ ${ }^{3}$ Department of Microbiology, Moyne Institute, Trinity College, Dublin 2, Republic of Ireland
}

(Received 23 September 1992; revised 23 December 1992; accepted 2 February 1993)

\begin{abstract}
The effect of an agr mutation on expression of type 5 capsular polysaccharide (CP) by Staphylococcus aureus Newman was investigated in different complex and synthetic media. CP expression by the agr mutant was strongly reduced in certain media but slightly in others, indicating that $\mathrm{CP}$ synthesis is positively controlled by agr. $\mathrm{CP}$ expression occurred in the post-exponential growth phase in both wild-type and mutant strains, suggesting that other regulatory systems could act in conjunction with agr.
\end{abstract}

\section{Introduction}

Capsular polysaccharides (CP) are produced by more than $90 \%$ of Staphylococcus aureus strains, and probably contribute to their virulence by increasing their resistance to phagocytosis (Karakawa et al., 1985, 1988; Karakawa \& Vann, 1982; Sompolinsky et al., 1985). Among the eight capsular serotypes described, type 5 and type 8 account for about 70 to $80 \%$ of all isolates (Boutonnier et al., 1989; Hochkeppel et al., 1987; Lee et al., 1990). Types 5 and $8 \mathrm{CP}$ have been covalently coupled to Pseudomonas aeruginosa toxin A to form highly immunogenic conjugate vaccines and to test the hypothesis that antibodies specific for $\mathrm{CP}$ are protective against invasive diseases caused by $S$. aureus (Fattom et al., 1990; Fournier, 1991).

During an investigation of the physiology of type $5 \mathrm{CP}$ biosynthesis (Dassy et al., 1991; Stringfellow et al., 1991), it was shown that the specific yield of $\mathrm{CP}$ varied from one medium to another, and that the rate of $\mathrm{CP}$ production relative to the cell mass increased during the post-exponential phase of growth, suggesting that $\mathrm{CP}$ biosynthesis was regulated in a similar fashion to exoproteins involved in virulence (Foster, 1991). The

* Author for correspondence. Unité Choléra et Vibrions, Département d'Ecologie, Institut Pasteur, F-75724 Paris Cedex 15, France. Tel. 145688220 ; fax 145688223.

Abbreviations: CP, capsular polysaccharide; MFM-YE, modified Frantz medium plus yeast extract diffusate; SEM, supplemented Eagle medium. genes affecting capsule expression have recently been cloned from $S$. aureus strain $\mathrm{M}$, a type $1 \mathrm{CP}$ producer (Lee, 1992). Most of these genes appear to be clustered together on an $11 \mathrm{~kb}$ fragment. The capsular and exopolysaccharide genes of other bacteria are also clustered (Deretic et al., 1991; Gray \& Rolfe, 1990; Gottesman \& Stout, 1991; Kroll, 1992). This clustering may facilitate coordinated expression and efficient regulation of $\mathrm{CP}$ biosynthetic genes.

The expression of extracellular and cell-bound proteins in $S$. aureus is controlled by a regulatory locus called accessory gene regulator ( $a g r)$. Most of these exoproteins, many of which play a role in the pathogenesis of $S$. aureus infections, are positively regulated by agr and are mainly produced after the cessation of active exponential growth (Janzon \& Arvidson, 1990; Peng et al., 1988; Recsei et al., 1986; Vandenesch et al., 1992). The similarity between the temporal production of exoproteins and $\mathrm{CP}$, and the fact that $\mathrm{CP}$ is also a potential virulence factor, prompted us to test the hypothesis that $\mathrm{CP}$ expression is controlled by $a g r$.

In the present study, we compared the wild-type $S$. aureus strain Newman with its corresponding agr mutant for type $5 \mathrm{CP}$ and exoprotein expression during growth in complex and synthetic media.

\section{Methods}

Bacterial strains and plasmids. S. aureus strain Newman (NCTC 8178) is a high producer of coagulase and clumping factor (Duthie \& Lorenz, 1952; McDevitt et al., 1992; Marston \& Fahlberg, 1960). Strain DU 
5869 is an agr mutant of strain Newman constructed by transducing the agr A : :Tn551 mutation from strain ISP546 (Recsei et al., 1986) using bacteriophage 85 . Strain ISP546 is a derivative of strain $8325-4$ (Novick, 1967). Plasmid pRN6650 (pUC18 with the complete agr locus of strain 8325-4 cloned on a $6.1 \mathrm{~kb}$ insertion; Peng et al., 1988) was kindly supplied by R. Novick (Public Health Research Institute, New York, USA).

DNA manipulation. Genomic DNA was isolated from $S$. aureus by the method of Pattee \& Neveln (1975). DNA manipulation and hybridization were performed by standard techniques (Ausubel $e t$ al., 1987).

Culture media. The modified Frantz medium (MFM-YE) is a semisynthetic medium containing mineral salts, glutamic acid, cystine, lactose and yeast extract diffusate (Difco). Complex and semi-synthetic media were as described previously (Dassy et al., 1991). Supplemented Eagle medium (SEM) and Base-21, containing mineral salts, nicotinamide, thiamine and amino acids, are synthetic media described by Stringfellow et al. (1991). Rabbit blood agar was from Sanofi Diagnostics Pasteur, France.

Growth conditions. Agar slants were incubated at $37^{\circ} \mathrm{C}$ with loose caps permitting good air exchange. Flasks were inoculated with $2 \%$ $(\mathrm{v} / \mathrm{v})$ of their liquid volume $(200 \mathrm{ml})$ from an overnight culture in the same medium, and placed in a rotary water-bath shaker (200 r.p.m.) at $37^{\circ} \mathrm{C}$.

Bacterial growth was followed by measuring the $\mathrm{OD}_{620}$ of an appropriate dilution of the cell suspension.

Type 5 CP assay. The total type 5 CP content was measured by a two-step inhibition enzyme-linked immunosorbent assay using monoclonal antibodies as previously described (Boutonnier et al., 1989; Dassy et al., 1991).

Haemolysin. Haemolytic activity in the culture supernatant was determined according to Duncan \& Cho (1971). One haemolytic unit (HU) is defined as that amount which liberated half of the haemoglobin in the test rabbit red cell suspension.

Acid phosphatase. Phosphatase activity in the culture supernatant was determined according to Barnes \& Morris (1957), with some modifications. The substrate, $p$-nitrophenylphosphate (Sigma), was dissolved in $0.15 \mathrm{M}$-acetate buffer, $\mathrm{pH} 5 \cdot 5$, containing $0.01 \mathrm{M}-\mathrm{MgSO}_{4}$ at a concentration of $1 \mathrm{mg} \mathrm{ml}^{-1}$. A $0 \cdot 1 \mathrm{ml}$ sample was added to $1 \mathrm{ml}$ of the substrate solution, and the reaction mixture was incubated for $30 \mathrm{~min}$ at $37^{\circ} \mathrm{C}$. The reaction was terminated by adding $2 \mathrm{ml} 0.075 \mathrm{M}-\mathrm{NaOH}$, and the yellow colour was measured as $A_{400}$. The spectrophotometer was adjusted to zero with a blank to which $0.1 \mathrm{ml}$ non-inoculated medium was added instead of the sample. One unit of phosphatase activity was defined as the amount of enzyme which liberated $1 \mu \mathrm{mol}$ $p$-nitrophenol $\mathrm{h}^{-1}$.

\section{Results}

\section{S. aureus strain Newman agr::Tn551}

In order to test the role of the agr regulatory locus in expression of $\mathrm{CP}$, the well-characterized agr $A:: \operatorname{Tn} 551$ mutation carried by the 8825-4 strain ISP546 was transduced into strain Newman, a strain which expresses type $5 \mathrm{CP}$. Erythromycin-resistant transductants were devoid of haemolytic activity for rabbit erythrocytes and produced elevated levels of protein A, characteristics of agr mutants of strain 8325-4 (Recsi et al., 1986). Genomic DNA from one transductant (DU5869) was analysed by Southern hybridization. A single HindIII fragment of greater than $16 \mathrm{~kb}$ hybridized to the agr probe pRN6650 in the parental strain, while two fragments of $13 \mathrm{~kb}$ and $10 \mathrm{~kb}$ from the mutant reacted with the probe DNA (data not shown). The $5.4 \mathrm{~kb}$ transposon Tn 551 carries two HindIII sites. The same results were obtained when DNA from strains 8325-4 and ISP546 was probed (data not shown). This shows that the agr locus was disrupted in strain DU5869 and that the agr::Tn551 mutation was acquired by homologous recombination.

\section{Production of exoproteins by S. aureus strains Newman and DU5869}

In all the liquid media tested (Table 1), strain Newman produced haemolytic activity toward rabbit erythrocytes, while the haemolysin titres of the $\mathrm{Agr}^{-}$strain DU5869 were lower. In contrast, phosphatase production appeared to be little affected (data not shown).

\section{Expression of type 5 CP by strains Newman and DU5869}

The pattern of production of type $5 \mathrm{CP}$ by strain Newman in different liquid media (Table 1) was closely related to that observed previously with strain Reynolds, the prototype strain for type 5 CP (Dassy et al., 1991; Stringfellow et al., 1991). MFM-YE and medium 110 gave the highest yields. Similar results were obtained after overnight growth on different agar slants media (data not shown).

The $\mathrm{Agr}^{-}$strain DU5869 produced no detectable type $5 \mathrm{CP}$ in Brain Heart Infusion, Nutrient Broth and Mueller-Hinton media. However, very slow but significant amounts were detected in Columbia and 110 media, and substantial amounts were obtained in MFMYE, synthetic SEM and Base-21 media. These levels were lower than that of the corresponding parental strain, and substantial variations were observed from one experiment to another resulting in relative high standard error values. Similar results were obtained after overnight growth on different media as agar slants (data not shown).

\section{Production of haemolysin and type 5 CP during growth in batch culture}

Haemolysin and type $5 \mathrm{CP}$ production by strains Newmann and DU5869 were measured during growth in MFM-YE in shake flasks.

Strain Newman (Fig. 1) grew exponentially for $3 \mathrm{~h}$, 
Table 1. Type 5 CP and haemolysin production by S. aureus strains Newman and DU5869 $\left(\mathrm{Agr}^{-}\right)$growth for $24 \mathrm{~h}$ at $37^{\circ} \mathrm{C}$ in shake flasks

Data shown are means \pm SEM of 3 independent experiments.

\begin{tabular}{lccccc}
\hline Liquid medium & Strain & $\begin{array}{c}\text { Growth } \\
\left(\mathrm{OD}_{620}\right)\end{array}$ & $\mathrm{pH}$ & $\begin{array}{c}\text { Type } 5 \mathrm{CP} \\
\left(\mathrm{ng} \mathrm{ml}^{-1}\right)\end{array}$ & $\begin{array}{c}\text { Haemolysin } \\
\left(\mathrm{HU} \mathrm{ml}^{-1}\right)\end{array}$ \\
\hline Brain Heart Infusion & Newman & $9 \cdot 70 \pm 0 \cdot 14$ & $8 \cdot 23 \pm 0 \cdot 32$ & $2200 \pm 330$ & $1100 \pm 400$ \\
& DU5869 & $11 \cdot 0 \pm 0 \cdot 50$ & $8 \cdot 23 \pm 0 \cdot 35$ & $<1$ & $155 \pm 100$ \\
Nutrient Broth & Newman & $1 \cdot 75 \pm 0 \cdot 35$ & $8 \cdot 19 \pm 0 \cdot 35$ & $470 \pm 340$ & $260 \pm 50$ \\
& DU5869 & $2 \cdot 0 \pm 0 \cdot 46$ & $8 \cdot 23 \pm 0 \cdot 33$ & $<1$ & $<1$ \\
Mueller-Hinton & Newman & $1 \cdot 70 \pm 0 \cdot 17$ & $7 \cdot 80 \pm 0 \cdot 28$ & $260 \pm 170$ & $50 \pm 27$ \\
& DU5869 & $2 \cdot 12 \pm 0 \cdot 12$ & $7 \cdot 86 \pm 0 \cdot 33$ & $<1$ & $<1$ \\
Columbia & Newman & $10 \cdot 30 \pm 0 \cdot 57$ & $8 \cdot 17 \pm 0 \cdot 28$ & $5800 \pm 2300$ & $630 \pm 400$ \\
& DU5869 & $11 \cdot 70 \pm 0 \cdot 30$ & $7 \cdot 93 \pm 0 \cdot 02$ & $50 \pm 10$ & $195 \pm 25$ \\
Medium 110 & Newman & $6 \cdot 71 \pm 0 \cdot 27$ & $4 \cdot 86 \pm 0 \cdot 16$ & $7300 \pm 1300$ & $90 \pm 70$ \\
& DU5869 & $5 \cdot 33 \pm 0 \cdot 57$ & $4 \cdot 60 \pm 0 \cdot 11$ & $75 \pm 61$ & $<2$ \\
MFM-YE & Newman & $3 \cdot 04 \pm 0 \cdot 35$ & $7 \cdot 66 \pm 0 \cdot 26$ & $4300 \pm 2400$ & $160 \pm 60$ \\
& DU5869 & $2 \cdot 90 \pm 0 \cdot 12$ & $7 \cdot 41 \pm 0 \cdot 03$ & $1000 \pm 1300$ & $<1$ \\
SEM & Newman & $1 \cdot 25 \pm 0 \cdot 30$ & $6 \cdot 43 \pm 0 \cdot 31$ & $1900 \pm 1300$ & ND \\
Base-21 & DU5869 & $1 \cdot 94 \pm 0 \cdot 11$ & $5 \cdot 70 \pm 0 \cdot 41$ & $450 \pm 100$ & ND \\
& Newman & $7 \cdot 16 \pm 0 \cdot 90$ & $7 \cdot 30 \pm 0 \cdot 14$ & $2200 \pm 1500$ & ND \\
& DU5869 & $7 \cdot 65 \pm 1 \cdot 18$ & $7 \cdot 45 \pm 0 \cdot 42$ & $260 \pm 240$ & ND \\
\hline \hline
\end{tabular}

ND, not determined.

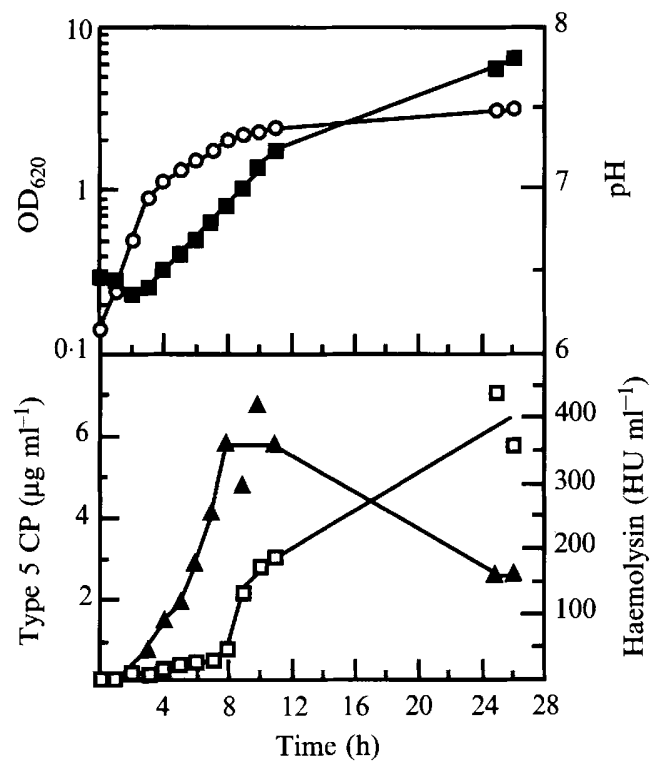

Fig. 1. Growth $(O), \mathrm{pH}(\square)$, type $5 \mathrm{CP}$ production $(\square)$ and haemolysin production $(\boldsymbol{A})$ by $S$. aureus strain Newman in MFM-YE medium in a shake flask at $37^{\circ} \mathrm{C}$.

followed by a slow growth phase for a further $8 \mathrm{~h}$. Haemolysin activity increased exponentially for $8 \mathrm{~h}$, then reached a plateau at 8 to $11 \mathrm{~h}$, before falling between 11 and $25 \mathrm{~h}$. The level of type $5 \mathrm{CP}$ first increased slowly for $8 \mathrm{~h}$, and then, after a pronounced rise between 8 and $11 \mathrm{~h}$, increased at a lower rate for $14 \mathrm{~h}$. The $\mathrm{pH}$ decreased for $2 \mathrm{~h}$ and then increased between 2 and $26 \mathrm{~h}$.

The plot of exoprotein and CP concentration vs extent

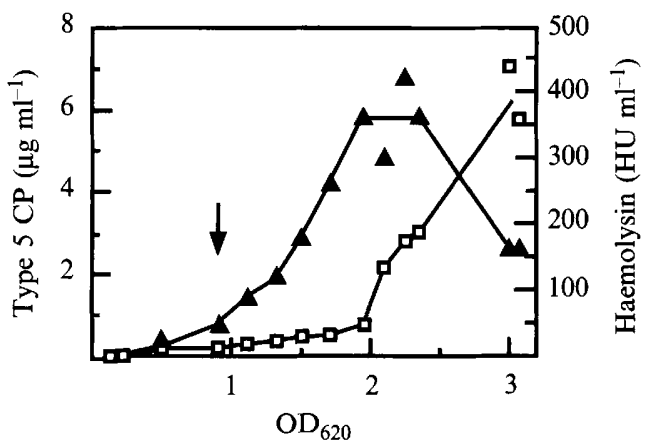

Fig. 2. Relationship between type 5 CP production ( $\square$ ) haemolysin production $(\mathbf{\Delta})$ and growth of $S$. aureus strain Newman. The arrow indicates the end of the exponential growth phase. The data are from the experiment depicted in Fig. 1.

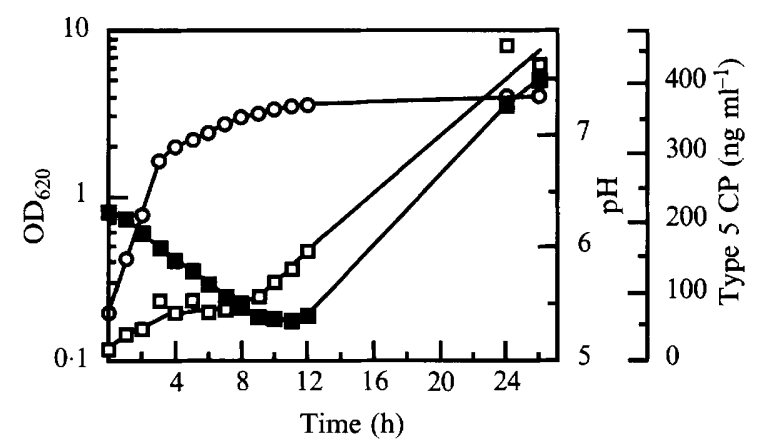

Fig. 3. Growth (O), pH ( $\square$ ) and type $5 \mathrm{CP}$ production ( $\square$ ) by $S$. aureus strain DU5869 in MFM-YE medium in a shake flask at $37^{\circ} \mathrm{C}$.

of growth (Fig. 2) shows the differential rates of expression (Coleman et al., 1978; Monod et al., 1952). The differential rates for each factor increased at different 


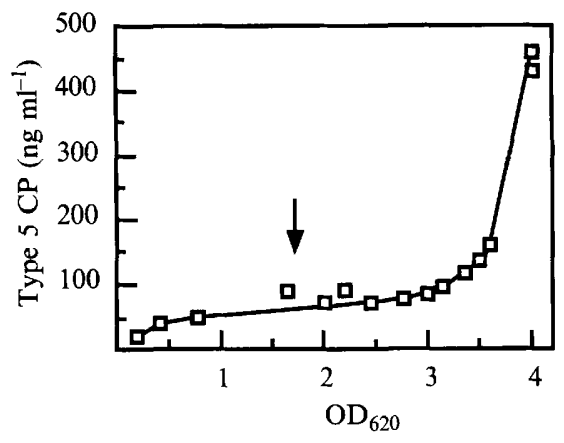

Fig. 4. Relationship between type 5 CP production and growth of $S$. aureus strain DU5869. The arrow indicates the end of the exponential growth phase. The data are from the experiment depicted in Fig. 3.

stages of growth; at the end of the exponential phase for haemolysin, and at the end of the slow growth phase for CP.

The Agr $^{-}$strain DU5869 (Fig. 3) showed similar growth and type $5 \mathrm{CP}$ production to that observed with strain Newman. No haemolytic activity was detectable. The $\mathrm{pH}$ decreased for at least $11 \mathrm{~h}$ and then increased. The variations in the differential rate of $\mathrm{CP}$ formation (Fig. 4) were also similar to those observed with strain Newman.

\section{Discussion}

The $\mathrm{Agr}^{-}$mutant of strain Newman exhibited a similar phenotype to $\mathrm{Agr}^{-}$mutants of other strains of $S$. aureus with respect to the regulation of exoprotein synthesis (Björklind \& Arvidson, 1980; Engels \& Kamps, 1982). They showed a drastic reduction of haemolytic activity and a slight reduction in phosphatase production.

The kinetics of haemolysin production by strain Newman were closely related to those observed with other S. aureus strains (Duncan \& Cho, 1971; Jassim et al., 1989). It was assumed that the decrease in haemolytic activity during the stationary phase was the result of denaturation caused by continued shaking at $37^{\circ} \mathrm{C}$. The haemolysin produced by strain Newman is probably $\gamma$ toxin. The haemolytic zone around colonies growing on agar plates incorporating rabbit erythrocytes was enhanced substantially when the medium was made up with agarose which lacks the sulphonated polymers known to inhibit $\gamma$-toxin (Clyne et al., 1992). Furthermore, antiserum to $\gamma$-toxin (obtained from M. Clyne, Trinity College, Dublin) inhibited haemolysis (data not shown). Strain Newman probably does not express significant amounts of $\alpha$-toxin, because transduction of the hla:: $\mathrm{Em}^{\mathrm{r}}$ mutation (O'Reilly et al., 1986) into this strain did not affect the size of haemolysis on agar plates incorporating rabbit erythrocytes.
Strain Newman has previously been grown in chemically defined media (Marston \& Fahlberg, 1960), and CP was shown to be produced by $S$. aureus in such media (Stringfellow et al., 1991). Significant differences for total growth and final $\mathrm{pH}$ between $\mathrm{Agr}^{+}$and $\mathrm{Agr}^{-}$ strains was only observed with synthetic SEM medium, which contains limited amounts of essential amino acids (Stringfellow et al., 1991). Moreover, differences were observed in the $\mathrm{pH}$ changes that occurred during growth of the $\mathrm{Agr}^{+}$and $\mathrm{Agr}^{-}$strains, suggesting a difference in metabolism. Recsei et al. (1986) showed that intracellular proteins as well as exoproteins were regulated by $a g r$.

The kinetics of type $5 \mathrm{CP}$ production by strains Newman and Reynolds were subtly but significantly different. The increase of the differential rate of $C P$ formation occurred at the end of the exponential phase for strain Reynolds (Dassy et al., 1991) and at the end of the slow growth phase for strain Newman. This indicates that regulation of type $5 \mathrm{CP}$ expression may be more complex than that of exoproteins. In addition, $\mathrm{CP}$ expression appears to be positively controlled by agr. However, this agr control seems to be partially overruled in MFM-YE, SEM and Base- 21 media, and the expression of CP by the agr mutant in MFM-YE also occurs in the post-exponential growth phase. This agr override could be due to the presence of a single medium component acting as a signal for the sensor protein of a two-component regulatory system (Gross et al., 1989; Stock et al., 1989) or to the effect that these media have on the metabolism of the bacteria. This suggests that another regulatory mechanism can interact with $a g r$, and is consistent with the interaction of distinct sensorregulator systems observed among other bacteria (Wanner, 1992), and with previous observations relating to the expression of exoproteins by $S$. aureus which suggested that other regulatory systems could act in conjunction with agr (Coleman et al., 1989; Compagnone-Post et al., 1991; Janzon et al., 1986; Regassa et al., 1991, 1992; Smeltzer et al., 1992; Vandenesch et al., 1992). A regulatory locus affecting exoprotein expression and distinct from $a g r$ was recently identified in S. aureus (Cheung et al., 1992).

Recently, agr expression was shown to be affected by the $\mathrm{pH}$ of the culture medium (Regassa \& Betley, 1992). Alkaline $\mathrm{pH}$ results in a decrease in agr expression and consequently in the expression of agr target genes. This is consistent with our previous results showing that postexponential $\mathrm{CP}$ production was observed in the $\mathrm{pH}$ range 6-7, but not at pH 8 (Dassy et al., 1991).

Some coagulase-negative staphylococci have been shown to produce extracellular proteins (Donham et al., 1988) and slime (Bayston \& Rodgers, 1990), mostly during the post-exponential growth phase. It is tempting to speculate that these species possess a common 
regulatory mechanism exhibiting some homologies with S. aureus agr.

During bacterial infections, the pathogenic organism uses adaptative responses to sense environmental conditions. These responses require the coordinate expression of a number of bacterial genes, many of which play a role in virulence (Dorman, 1991; Mekalanos, 1992). The genetics of capsule and exopolysaccharide expression have been examined in several bacterial species (Deretic et al., 1991; Frosch et al., 1991; Gray \& Rolfe, 1990; Gottesman \& Stout, 1991; Kroll, 1992), but it has only recently been shown that elements of genetic regulation of exoprotein and exopolysaccharide were shared in Xanthomonas campestris (Tang et al., 1990, 1991) and Pseudomonas aeruginosa (Cacalano et al., 1992). Our results show that the same situation occurs in $S$. aureus. Further investigation of the molecular genetics of $S$. aureus capsule expression and its regulation is now warranted.

We are grateful to F. Nato and J. C. Mazié (Hybridolab, Institut Pasteur, Paris) for providing monoclonal antibodies to $S$. aureus type 5 capsular polysaccharide.

\section{References}

Ausubel, F. M., Brent, R., Kingston, R. E., Moore, D. D., Smith, J. A., Seidman, J. G. \& Struhl, K. (1987). Current Protocols in Molecular Biology. New York: John Wiley and Sons.

Barnes, E. H. \& MorRIS, J. F. (1957). A quantitative study of the phosphatase activity of Micrococcus pyogenes. Journal of Bacteriology 73, 100-104.

Bayston, R. \& Rodgers, J. (1990). Production of extra-cellular slime by Staphylococcus epidermidis during stationary phase of growth: its association with adherence to implantable devices. Journal of Clinical Pathology 43, 866-870.

BJörklind, A. \& ARvidson, S. (1980). Mutants of Staphylococcus aureus affected in the regulation of exoprotein synthesis. FEMS Microbiology Letters 7, 203-206.

Boutonnier, A., Nato, F., Bouvet, A., Lebrun, L., Audurier, A., Mazie, J. C. \& Fournier, J. M. (1989). Direct testing of blood cultures for detection of the serotype 5 and 8 capsular polysaccharides of Staphylococcus aureus. Journal of Clinical Microbiology 27, 989-993.

Cacalano, G., Kays, M., Saiman, L. \& Prince, A. (1992). Production of the Pseudomonas aeruginosa neuraminidase is increased under hyperosmolar conditions and is regulated by genes involved in alginate expression. Journal of Clinical Investigation 89, 1866-1874.

Cheung, A. L., Koomey J. M., Butler, C. A., Projan, S. J. \& FischetTI, V. A. (1992). Regulation of exoprotein expression in Staphylococcus aureus by a locus (sar) distinct from agr. Proceedings of the National Academy of Sciences of the United States of America 89, 6462-6466.

Clyne, M., Birkbeck, T. H. \& Arbuthnott, J. P. (1992). Characterization of staphylococcal $\gamma$-lysin. Journal of General Microbiology 138, 923-930.

Coleman, G., Aboshkiwa, M. \& Al-Ani, B. (1989). The effect of glucose on the expression of extracellular protein genes by Staphylococcus aureus strain V8. FEMS Microbiology Letters 61, $247-250$.

Coleman, G., Jakeman, C. M. \& Martin, N. (1978). Patterns of total extracellular protein secretion by a number of clinically isolated strains of Staphylococcus aureus. Journal of General Microbiology 107, 189-192.

Compagnone-Post, P., Malyankar, U. \& Khan, S. A. (1991). Role of host factors in the regulation of the enterotoxin B gene. Journal of Bacteriology 173, 1827-1830.

Dassy, B., Stringfellow, W. T., Lieb, M. \& Fournier, J. M. (1991). Production of type 5 capsular polysaccharide by Staphylococcus aureus grown in a semi-synthetic medium. Journal of General Microbiology 137, 1155-1162.

Deretic, V., Mohr, C. D. \& Martin, D. W. (1991). Mucoid Pseudomonas aeruginosa in cystic fibrosis: signal transduction and histone-line elements in the regulation of bacterial virulence. Molecular Microbiology 5, 1577-1583.

Donham, M. C., Heth, H. E., LeBlanc, P. A. \& Sloan, G. L. (1988). Characteristics of extracellular protein production by Staphylococcus simulans biovar staphylolyticus during aerobic and anaerobic growth. Journal of General Microbiology 134, 2615-2621.

DORMAN, C. J. (1991). DNA supercoiling and environmental regulation of gene expression in pathogenic bacteria. Infection and Immunity $\mathbf{5 9}$, $745-749$.

Duncan, J. L. \& Cho, G. J. (1971). Production of staphylococcal alpha toxin. I. Relationship between cell growth and toxin formation. Infection and Immunity 4, 456-461.

DuthIE, E. S. \& LoRENZ, L. L. (1952). Staphylococcal coagulase: mode of action and antigenicity. Journal of General Microbiology 6, 95-107.

ENGELs, W. \& KaMPS, M. A. F. (1982). The nature of the competitive ability of spontaneous staphylocoagulase-negative mutants of Staphylococcus aureus with respect to growth of the parent strains in continuous culture. Antonie van Leeuwenhoek 48, 67-83.

Fattom, A., Schneerson, R., Szu, S. C., Van, W. F., Shiloach, J., Karakawa, W. W. \& Robbins, J. B. (1990). Synthesis and immunologic properties in mice of vaccines composed of Staphylococcus aureus type 5 and type 8 capsular polysaccharides conjugated to Pseudomonas aeruginosa exotoxin A. Infection and Immunity 58, 2367-2374.

FOSTER, T. J. (1991). Potential for vaccination against infections caused by Staphylococcus aureus. Vaccine 9, 221-227.

FouRNIER, J. M. (1991). Staphylococcus aureus. In Vaccines and Immunotherapy, pp. 166-177. Edited by S. J. Cryz, Jr. New York: Pergamon Press.

Frosh, M., Edwards, U., Bousset K., Krauße, B. \& Weisgerber, C. (1991). Evidence for a common molecular origin of the capsule gene loci in Gram-negative bacteria expressing group II capsular polysaccharides. Molecular Microbiology 5, 1251-1263.

GotTesman, S. \& STOUT, V. (1991). Regulation of capsular polysaccharide synthesis in Escherichi coli K12. Molecular Microbiology 5, 1599-1606.

GraY, J. X. \& Rolfe, B. G. (1990). Exopolysaccharide production in Rhizobium and its role in invasion. Molecular Microbiology 4, $1425-1431$.

Gross, R., Arico, B. \& Rappuoli, R. (1989). Families of bacterial signal-transducing proteins. Molecular Microbiology 3, 1661-1667.

HochKePpel, H. K., Braun, D. G., Vischer, W., IMM, A., SUTter, J., Staeubli, U., Guggenheim, R., Kaplan, E. L., Boutonnier, A. \& FOURNIER, J. M. (1987). Serotyping and electron microscopy studies of Staphylococcus aureus clinical isolated with monoclonal antibodies to capsular polysaccharide types 5 and 8 . Journal of Clinical Microbiology 25, 526-530.

JANZON, L. \& ARVIDSON, S. (1990). The role of the $\delta$-lysin gene (hld) in the regulation of virulence genes by the accessory gene regulator (agr) in Staphylococcus aureus. EMBO Journal 9, 1391-1399.

JANZON, L., LÖFDAHL, S. \& ARVIDSON, S. (1986). Evidence for a coordinate transcriptional control of alpha-toxin and protein $\mathrm{A}$ synthesis in Staphylococcus aureus. FEMS Microbiology Letters 33, 193-198.

Jassim, S., Salt, W. G. \& Stretton, R. J. (1989). In vitro studies of haemolysis by some staphylococci grown in chemically defined media. Journal of Applied Bacteriology 67, 511-520.

Karakawa, W. W., Fournier, J. M., VANN, W. F., Arbeit, R., SCHNEERSON, R. S. \& RobBins, J. B. (1985). Method for the serological typing of the capsular polysaccharides of Staphylococcus aureus. Journal of Clinical Microbiology 22, 445-447.

Karakawa, W. W., Sutton, A., Schneerson, R. S., Karpas, A. \& VANN, W. F. (1988). Capsular antibodies induce type-specific 
phagocytosis of capsulated Staphylococcus aureus by human polymorphonuclear leukocytes. Infection and Immunity 56, 1090-1095.

KarakaWa, W. W. \& VANN, W. F. (1982). Capsular polysaccharides of Staphylococcus aureus. In Seminars in Infectious Disease: Bacterial Vaccines, vol. 4, pp. 285-293. Edited by J. B. Robbins, J. C. Hill and J. C. Sadoff. New York: Thieme Stratton.

Kroll, J. S. (1992). The genetics of encapsulation in Haemophilus influenzae. Journal of Infectious Diseases 165, S93-S96.

LEE, C. Y. (1992). Cloning of genes affecting capsule expression in Staphylococcus aureus strain M. Molecular Microbiology 6, $1515-1522$.

Lee, J. C., Liu, M. J., Parsonnet, J. \& Arbeit, R. D. (1990). Expression of type 8 capsular polysaccharide and production of toxic shock syndrome toxin 1 are associated among vaginal isolates of Staphylococcus aureus. Journal of Clinical Microbiology 28, 2612-2615.

MARSTON, J. \& FAHLBerg, W. J. (1960). Coagulase production by Staphylococcus aureus. II. Growth and coagulase production in complex and chemically defined mediums. Journal of Infectious Diseases 106, 116-122.

McDevitT, D., Vaudaux, P. \& Foster, T. J. (1992). Genetic evidence that bound coagulase of Staphylococcus aureus is not clumping factor. Infection and Immunity 60, 1514-1523.

Mekalanos, J. J. (1992). Environmental signals controlling expression of virulence determinants in bacteria. Journal of Bacteriology 174, $1-7$.

Monod, J., Pappenheimer, Jr, A. M. \& Cohen-Bazire, G. (1952). La cinétique de la biosynthèse de la $\beta$-galactosidase chez $E$. coli considérée comme fonction de la croissance. Biochimica et Biophysica Acta 9, 648-660.

Novick, R. P. (1967). Properties of a cryptic high-frequency transducing phage in Staphylococcus aureus. Virology 33, 155-166.

O'Reilly, M., De Azavedo, C. S., Kennedy, S. \& Foster, T. J. (1986). Inactivation of the alpha-haemolysin gene of Staphylococcus aureus 8325-4 by site-directed mutagenesis and studies on the expression of its haemolysins. Microbial Pathogenesis 1, 125-138.

Pattee, P. A. \& Neveln, D. S. (1975). Transformation analysis of three linkage groups in Staphylococcus aureus. Journal of Bacteriology 124, 201-211.

Peng, H. L., Novick, R. P., Kreiswirth, B., Kornblum, J. \& SCHLIEVERT, P. (1988). Cloning, characterisation, and sequencing of an accessory gene regulator (agr) in Staphylococcus aureus. Journal of Bacteriology 170, 4365-4372.

Recsei, P., Kreiswirth, B., O'Reilly, M., Schlievert, P., Gruss, A. \& Novick, R. P. (1986). Regulation of exoprotein gene expression in Staphylococcus aureus by agr. Molecular and General Genetics 202, 58-61.

Regassa, L. B. \& Betley, M. J. (1992). Alkaline pH decreases expression of the accessory gene regulator (agr) in Staphylococcus aureus. Journal of Bacteriology 174, 5095-5100.

Regassa, L. B., Couch, J. L. \& Betley, M. J. (1991). Steady-state staphylococcal enterotoxin type C mRNA is affected by a product of the accessory gene regulatory (agr) and by glucose. Infection and Immunity 59, 955-962.

Regassa, L. B., Novick, R. P. \& Betley, M. J. (1992). Glucose and nonmaintained $\mathrm{pH}$ decrease expression of the accessory gene regulator (agr) in Staphylococcus aureus. Infection and Immunity $\mathbf{6 0}$, 3381-3388.

Sompolinsky, D., Samra, Z., Karakawa, W. W., Vann, W. F., SCHNEERSON, R. \& MALIK, Z. (1985). Encapsulation and capsular types in isolates of Staphylococcus aureus from different sources and relationship to phage types. Journal of Clinical Microbiology 22 $828-834$.

Stock, J. B., Ninfa, A. J. \& Stock, A. M. (1989). Protein phosphorylation and regulation of adaptative responses in bacteria. Microbiological Reviews 53, 450-490.

Stringfellow, W. T., Dassy, B., Lieb, M. \& Fournier, J. M. (1991) Staphylococcus aureus growth and type 5 capsular polysaccharide production in synthetic media. Applied and Environmental Microbiology 57, 618-621.

TANG, J. L., Gough, C. L. \& Daniels, M. J. (1990). Cloning of genes involved in negative regulation of production of extracellular enzymes and polysaccharide of Xanthomonas campestris pathovar campestris. Molecular and General Genetics 222, 157-160.

TANG, J. L., LiU, Y. N., Barber, C. E., Dow, J. M., Wootton, J. C. \& DANIELS, M. J. (1991). Genetic and molecular analysis of a cluster of $r p f$ genes involved in positive regulation of synthesis of extracellular enzymes and polysaccharide in Xanthomonas campestris pathovar campestris. Molecular and General Genetics 226, 409-417.

VANDENesCh, F., Kornblum, J. \& Novick, R. P. (1991). A temporal signal independent of $a g r$, is required for hla but not spa transcription in Staphylococcus aureus. Journal of Bacteriology 173, 6313-6320.

WANNER, B. L. (1992). Is cross regulation by phosphorylation of twocomponent response regulator proteins important in bacteria? Journal of Bacteriology 174, 2053-2058. 